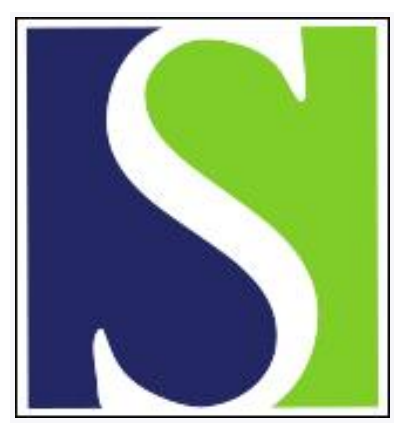

Scand J Work Environ Health 1986;12(4):378-381

https://doi.org/10.5271/sjweh.2125

Issue date: Aug 1986

Cardiovascular responses of vibration-exposed workers to a cold provocation test.

by Bovenzi M

This article in PubMed: www.ncbi.nlm.nih.gov/pubmed/3775327

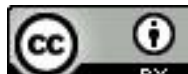




\title{
Cardiovascular responses of vibration-exposed workers to a cold provocation test
}

\author{
by Massimo Bovenzi, MD'
}

\begin{abstract}
BOVENZI M. Cardiovascular responses of vibration-exposed workers to a cold provocation test. Scand $J$ Work Environ Health 12 (1986) 378-381. Hemodynamic functions and changes in sympathetic nervous activity were assessed in 50 vibration-exposed workers without vibration-induced white finger (VWF), in 13 subjects with VWF, and in 41 referents. Indices of systolic time intervals such as the electromechanical systole index $\left(\mathrm{QS}_{2} \mathrm{I}\right)$ and the left ventricular ejection time index (LVETI) were found to be significantly shorter in the vibration workers than in the referents both at rest and during a cold provocation test. A significant inverse relationship between urinary levels of free catecholamines and the duration of the LVETI was observed under resting conditions. The recovery rate of the basal finger skin temperature after cold provocation was slower in the vibration-exposed workers than in the referents. The indices of platelet aggregation were about the same in all the groups studied. The results of this investigation suggest that cardiac sympathetic tone and digital vascular reactivity to cold are increased in vibration-exposed workers.
\end{abstract}

Key terms: finger skin temperature, sympathetic nervous system, systolic time intervals, vibration-induced white finger.

The episodic vasospasm that occurs in the fingers of workers exposed to hand-arm vibration is considered to be a secondary form of Raynaud's phenomenon. It is also called vibration-induced white finger (VWF). The pathogenesis of VWF is not completely known. An increased output of the sympathetic nervous system and/or local alterations in the digital vessels are thought to be the main pathophysiological mechanisms for the development of VWF (3). It has also been suggested that Raynaud's phenomenon of occupational origin may be related to endothelial damage due to the enhancement of shear stress on the arterial walls by segmental vibration (6). The present study was designed to assesss the level of sympathetic nervous system activity in a group of vibration-exposed foundry workers. For this purpose the cardiovascular responses to a cold provocation test were evaluated through the monitoring of blood pressures, heart rate, and time intervals of the left ventricular systole. Furthermore, to determine if endothelial injury is involved in the pathogenesis of VWF, platelet function was studied.

\section{Subjects and methods}

Sixty-three vibration-exposed foundry workers and 41 referents working at the same plant were examined (table 1). The referents were male subjects performing manual work and not exposed to hand-arm vibration.

\footnotetext{
1 Institute of Occupational Health, University of Trieste, Trieste, Italy.
}

Reprint requests to: Dr M Bovenzi, Istituto di Medicina del Lavoro, Università di Trieste, c/o Centro Tumori, Via della Pietà 19, I-34129 Trieste, Italy.
According to Taylor's stage assessment for VWF (7), nine vibration-exposed workers had no disturbances (stage 0 ) and 41 complained of neurological symptoms (stages $0_{\mathrm{T}}$ and $0_{\mathrm{N}}$ ). These workers formed the vibration-exposed group without VWF. The remaining 13 vibration-exposed workers suffered from VWF, nine being in stage 1 and four in stage 2 .

Cold provocation tests were performed in a room with an ambient temperature of 22.5 (SD 0.4) ${ }^{\circ} \mathrm{C}$. After a rest period of $20-30 \mathrm{~min}$ (in a supine position), the subjects' electrocardiogram, phonocardiogram, and external carotid pulse tracing were simultaneously recorded on a multichannel recorder (C6b Ote Biomedica) at a paper speed of $100 \mathrm{~mm} / \mathrm{s}$. From these recordings the base-line heart rate and systolic time intervals were obtained. Systolic and diastolic blood pressures were measured on the right arm with a mercury sphygmomanometer. The same cardiovascular parameters were monitored during and after the cold provocation [immersion of the right hand in ice water $\left(4^{\circ} \mathrm{C}\right)$ for $\left.2 \mathrm{~min}\right]$. Systolic time intervals such as total electromechanical systole $\left(\mathrm{QS}_{2}\right)$, left ventricular ejection time (LVET), and preejection period (PEP), were determined on the polygraphic tracings according to Weissler's method (8). The value of each systolic time interval (in milliseconds) was averaged from $8-10$ consecutive cardiac cycles. The intervals were corrected for the influence of heart rate by appropriate linear regression equations and expressed as indices $\left(\mathrm{QS}_{2} \mathrm{I}\right.$, LVETI, PEPI). To study the peripheral circulatory function in the reference and exposed groups, we measured skin temperature of the third finger of the right hand with a thermistor before and after the cold provocation test. 
Adenosine-diphosphate (ADP) and epinephrineinduced platelet aggregation, beta-thromboglobulin, and platelet factor four were determined as described in a previous paper (2). Assay of free catecholamines in urine was performed with a Bio Rad kit and a fluorometric method (4). With the use of Bio Rad columns (Bio Rex 70) the recovery for urinary catecholamines was 90 (SD 3) \%. The urine collections were made in the early morning over a $3 \mathrm{~h}$ period before the cold provocation test, and the levels of excreted catecholamines were adiusted for urinary creatinine.

\section{Results}

The results of the polygraphic recordings are reported in table 2. At rest the duration of the $\mathrm{QS}_{2} \mathrm{I}$ and the LVETI was shorter for the vibration-exposed workers than for the referents $(p<0.001)$. The workers with VWF, moreover, showed a shorter LVETI than those without VWF $(\mathrm{p}<0.05)$. Among the groups studied, no differences were found in the other cardiovascular parameters recorded under resting conditions.

The assay of free catecholamines from spot urine

Table 1. Characteristics of the vibration-exposed workers and the referents. (VWF = vibration-induced white finger)

\begin{tabular}{|c|c|c|c|c|c|c|}
\hline \multirow{3}{*}{ Variable } & \multirow{2}{*}{\multicolumn{2}{|c|}{$\begin{array}{l}\text { Referents } \\
(\mathrm{N}=41)\end{array}$}} & \multicolumn{4}{|c|}{ Vibration-exposed workers } \\
\hline & & & \multicolumn{2}{|c|}{$\begin{array}{l}\text { Without VWF } \\
(N=50)\end{array}$} & \multicolumn{2}{|c|}{$\begin{array}{l}\text { With VWF } \\
(N=13)\end{array}$} \\
\hline & Trean & (ה) & Mean & SD & Mean & SD \\
\hline $\begin{array}{l}\text { Age (years) } \\
\text { Height }(\mathrm{cm}) \\
\text { Weight }(\mathrm{kg}) \\
\text { Exposure time (years) } \\
\text { Total worktime (h) }\end{array}$ & $\begin{array}{c}39.4 \\
175 \\
80.8 \\
.\end{array}$ & $\begin{array}{r}6.4 \\
6.4 \\
12.2\end{array}$ & $\begin{array}{c}39.1 \\
173 \\
79.8 \\
8.7 \\
3213\end{array}$ & $\begin{array}{r}7.0 \\
5.3 \\
9.9 \\
5.8 \\
2239\end{array}$ & $\begin{array}{c}44.4 \\
172 \\
80.8 \\
16.8 \\
10622\end{array}$ & $\begin{array}{l}4.8^{*+} \\
5.7 \\
6.2 \\
6.2^{\star *} \\
5666^{* *}\end{array}$ \\
\hline
\end{tabular}

${ }^{*} p<0.02$, versus referents; ${ }^{+} p<0.02$ and ${ }^{* *} p<0.001$, versus vibration workers without VWF (unpaired Student's t-test).

Table 2. Blood pressures, heart rate, and systolic time interval indices [electromechanical systole $\left(\mathrm{QS}_{2}\right)$, left ventricular ejection time (LVET), preejection period (PEP)] measured in the vibration-exposed workers and in the referents at rest and during cold provocation. The significance of differences for paired observations (Student's t-test) is reported. (VWF = vibration-induced white finger, $N S=$ not significant)

\begin{tabular}{|c|c|c|c|c|c|c|c|c|c|}
\hline \multirow{3}{*}{ Variable } & \multirow{2}{*}{\multicolumn{3}{|c|}{$\begin{array}{l}\text { Referents } \\
(\mathrm{N}=41)\end{array}$}} & \multicolumn{6}{|c|}{ Vibration-exposed workers } \\
\hline & & & & \multicolumn{3}{|c|}{$\begin{array}{l}\text { Without VWF } \\
\qquad(N=50)\end{array}$} & \multicolumn{3}{|c|}{$\begin{array}{l}\text { With VWF } \\
(N=13)\end{array}$} \\
\hline & Mean & SD & $p$ & Mean & SD & $\mathrm{p}$ & Mean & SD & $p$ \\
\hline \multicolumn{10}{|l|}{$\begin{array}{l}\text { Systolic blood pressure } \\
\left(\mathrm{mm} \mathrm{Hg} \mathrm{Hg}^{\mathrm{a}}\right)\end{array}$} \\
\hline $\begin{array}{l}\text { At rest } \\
\text { During cold provocation }\end{array}$ & $\begin{array}{l}130 \\
156\end{array}$ & $\begin{array}{l}12.7 \\
21.2\end{array}$ & $<0.001$ & $\begin{array}{l}127 \\
151\end{array}$ & $\begin{array}{l}12.0 \\
13.9\end{array}$ & $<0.001$ & $\begin{array}{l}136 \\
156\end{array}$ & $\begin{array}{l}16.0 \\
14.7\end{array}$ & $<0.001$ \\
\hline $\begin{array}{l}\text { Diastolic blood pressure } \\
(\mathrm{mm} \mathrm{Hg})\end{array}$ & & & & & & & & & \\
\hline $\begin{array}{l}\text { At rest } \\
\text { During cold provocation }\end{array}$ & $\begin{array}{l}82.5 \\
105\end{array}$ & $\begin{array}{l}10.4 \\
13.3\end{array}$ & $<0.001$ & $\begin{array}{l}83.9 \\
104\end{array}$ & $\begin{array}{r}9.4 \\
11.4\end{array}$ & $<0.001$ & $\begin{array}{l}88.8 \\
107\end{array}$ & $\begin{array}{r}8.9 \\
10.1\end{array}$ & $<0.001$ \\
\hline $\begin{array}{l}\text { Heart rate (beats } / \mathrm{min} \text { ) } \\
\text { At rest } \\
\text { During cold provocation } \\
\mathrm{QS}_{2} \text { index (ms) }\end{array}$ & $\begin{array}{l}67.1 \\
74.5\end{array}$ & $\begin{array}{r}9.9 \\
12.4\end{array}$ & $<0.001$ & $\begin{array}{l}64.7 \\
71.7\end{array}$ & $\begin{array}{r}9.3 \\
11.3\end{array}$ & $<0.001$ & $\begin{array}{l}67.8 \\
73.3\end{array}$ & $\begin{array}{l}10.8 \\
13.5\end{array}$ & $<0.01$ \\
\hline $\begin{array}{l}\text { At rest } \\
\text { During cold provocation }\end{array}$ & $\begin{array}{l}571 \\
553\end{array}$ & $\begin{array}{l}16.2 \\
20.6\end{array}$ & $<0.001$ & $\begin{array}{l}542 \\
531\end{array}$ & $\begin{array}{l}13.8^{+} \\
16.2^{+}\end{array}$ & $<0.001$ & $\begin{array}{l}535 \\
527\end{array}$ & $\begin{array}{l}13.8^{+} \\
17.1^{+}\end{array}$ & $<0.001$ \\
\hline \multicolumn{10}{|l|}{ LVET index (ms) } \\
\hline $\begin{array}{l}\text { At rest } \\
\text { During cold provocation }\end{array}$ & $\begin{array}{l}423 \\
399\end{array}$ & $\begin{array}{l}11.9 \\
16.8\end{array}$ & $<0.001$ & $\begin{array}{l}396 \\
379\end{array}$ & $\begin{array}{l}11.8^{+} \\
12.8^{+}\end{array}$ & $<0.001$ & $\begin{array}{l}389 \\
375\end{array}$ & $\begin{array}{c}8.8^{*+} \\
11.0^{+}\end{array}$ & $<0.001$ \\
\hline \multicolumn{10}{|l|}{ PEP index (ms) } \\
\hline $\begin{array}{l}\text { At rest } \\
\text { During cold provocation } \\
\text { PEP:LVET (ratio) }\end{array}$ & $\begin{array}{l}147 \\
153\end{array}$ & $\begin{array}{l}12.8 \\
13.5\end{array}$ & $<0.001$ & $\begin{array}{l}145 \\
151\end{array}$ & $\begin{array}{l}13.3 \\
12.2\end{array}$ & $<0.001$ & $\begin{array}{l}145 \\
155\end{array}$ & $\begin{array}{l}11.0 \\
12.7\end{array}$ & $<0.001$ \\
\hline $\begin{array}{l}\text { At rest } \\
\text { During cold provocation }\end{array}$ & $\begin{array}{l}0.33 \\
0.34\end{array}$ & $\begin{array}{l}0.04 \\
0.05\end{array}$ & NS & $\begin{array}{l}0.33 \\
0.34\end{array}$ & $\begin{array}{l}0.05 \\
0.04\end{array}$ & NS & $\begin{array}{l}0.34 \\
0.35\end{array}$ & $\begin{array}{l}0.04 \\
0.05\end{array}$ & NS \\
\hline
\end{tabular}

a $1 \mathrm{~mm} \mathrm{Hg}=133.322$.

* $p<0.05$, versus the vibration-exposed workers without WWF; + $p<0.001$, versus referents (unpaired Student's t-test). 
Table 3. Urinary excretion of free catecholamines, platelet count, and results of the platelet aggregation tests of the vibrationexposed workers and the referents. (VWF $=$ vibration-induced white finger)

\begin{tabular}{|c|c|c|c|c|c|c|}
\hline \multirow{3}{*}{ Variable } & \multirow{2}{*}{\multicolumn{2}{|c|}{$\begin{array}{l}\text { Referents } \\
(N=41)\end{array}$}} & \multicolumn{4}{|c|}{ Vibration-exposed workers } \\
\hline & & & \multicolumn{2}{|c|}{$\begin{array}{l}\text { Without VWF } \\
\qquad(N=50)\end{array}$} & \multicolumn{2}{|c|}{$\begin{array}{l}\text { With VWF } \\
(N=13)\end{array}$} \\
\hline & Miean & 80 & Mean & SD & Mean & SD \\
\hline $\begin{array}{l}\text { Urinary free catecholamines } \\
(\mu \mathrm{g} / \mathrm{g} \text { of creatinine })\end{array}$ & 49.1 & 20.1 & 53.9 & 16.9 & 61.0 & 23.2 \\
\hline Platelet count $\left(\times 10^{3} / \mathrm{mm}^{3}\right)$ & 237 & 52.3 & 231 & 59.5 & 243 & 81.0 \\
\hline$A_{5}$ adenosine-diphosphate $(\%)$ & 43.0 & 26.2 & 53.4 & 61.2 & 44.0 & 32.1 \\
\hline$A_{5}$ epinephrine $(\%)$ & 45.7 & 21.7 & 40.6 & 20.5 & 38.0 & 32.2 \\
\hline $\begin{array}{l}\text { Adenosine-diphosphate (threshold) } \\
\left(\times 10^{-6} \mathrm{M}\right)\end{array}$ & 0.75 & 0.83 & 0.97 & 1.04 & 1.18 & 0.60 \\
\hline Beta-thromboglobulin (ng/ml) & 54.0 & 30.3 & 40.6 & $22.2^{*}$ & 59.9 & 39.8 \\
\hline Platelet factor four $(\mathrm{ng} / \mathrm{ml})$ & 15.6 & 14.5 & 11.3 & 7.6 & 15.5 & 19.0 \\
\hline
\end{tabular}

$* 0<0.02$, versus the referents (unpaired Student's t-test).

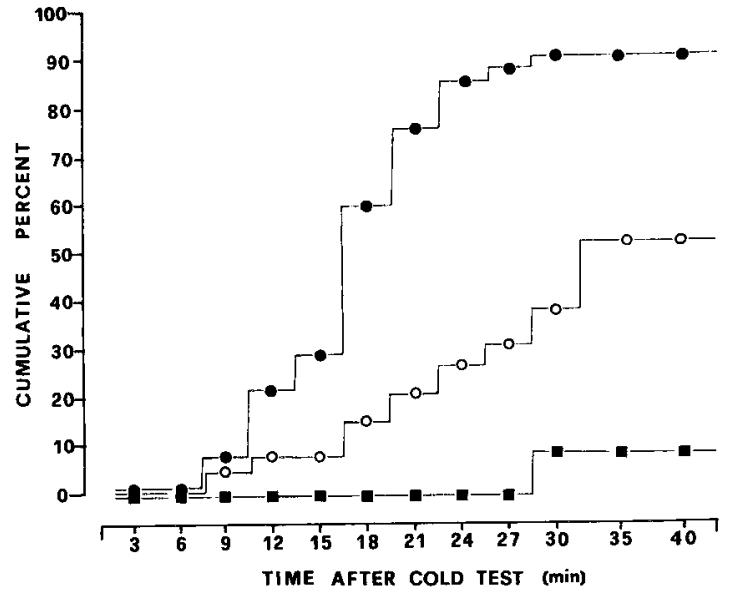

Figure 1. Recovery of the basal finger skin temperature in the referents $(O)$ and in the vibration-exposed workers without $(O)$ and with (ם) vibration-induced white finger (VWF) after the cold provocation test. Statistics (chi-square test): significant from referents: vibration workers without VWF at $15 \mathrm{~min}(p<0.025)$ and at $18-40 \mathrm{~min}(p<0.001)$ and vibration workers with VWF at $18-40 \mathrm{~min}(\mathrm{p}<0.001)$; significant from vibration workers without VWF: vibration workers with VWF at $35-40 \mathrm{~min}$ $(p<0.025)$

samples revealed that the vibration-exposed workers excreted larger amounts of catecholamines than the referents (table 3 ), but the differences were not significant. Nevertheless, for all the subjects a significant inverse relationship was found between the urinary levels of free catecholamines and the duration of LVETI at rest [correlation coefficient $(r)-0.23$, $p<0.03]$. The urinary excretion of free catecholamines correlated well even with the $\mathrm{QS}_{2}$, LVET, and heart rate $(0.005<\mathrm{p}<0.04)$.

In the vibration-exposed and reference groups the blood pressures, heart rate, and PEPI significantly increased during the cold provocation test, whereas the $\mathrm{QS}_{2} \mathrm{I}$ and LVETI significantly decreased (table 2). As under the resting conditions, both in connection with the cold provocation and during the recovery period, the vibration workers with and without VWF showed shorter $\mathrm{QS}_{2} \mathrm{I}$ and LVETI when compared to those of the referents $(p<0.001)$.

At rest the finger skin temperature was found to be lower in the foundry workers with VWF [31.6 (SD 1.5) $\left.{ }^{\circ} \mathrm{C}\right]$ than in the referents $\left[32.8\left(\right.\right.$ SD 1.8) $\left.{ }^{\circ} \mathrm{C}\right](\mathrm{p}<0.05)$. After the local cooling the recovery rate of the basal finger skin temperature was significantly slower in the subjects with VWF than in the other groups (figure 1). The cumulative percentage of exposed workers without VWF recovering the resting digital temperature was also significantly lower than that of the referents.

Tests of platelet aggregation in vitro (adenosinediphosphate, epinephrine) and platelet factor four were not different among the groups (table 3 ). The mean value of beta-thromboglobulin was found to be lower in the exposed workers without VWF, but the levels of this platelet protein was about the same in the other groups.

\section{Discussion}

It is well known that the duration of the systolic time intervals varies inversely with heart rate and that alterations in the intervals are related to changes in stroke volume, aortic pressure, and myocardial contractility (8). As a consequence, stress tests such as cold provocation of the hand can influence the systolic time intervals because of the hemodynamic changes caused by the increase of the sympathetic nervous system outflow. In the present study the vibration-exposed workers with and without VWF showed shortened systolic time intervals $\left(\mathrm{QS}_{2} \mathrm{I}, \mathrm{LVETI}\right)$ in comparison with the referents. The urinary excretion of free catecholamines was higher in the vibration groups, and it was inversely related to the duration of the LVETI.

These findings suggest that the level of cardiac sympathetic activity was increased in the foundry workers exposed to hand-arm vibration. This appraisal 
seems to be confirmed by other authors who studied patients and healthy subjects not exposed to vibration. Lewis et al (5) reported a direct relationship between the abbreviation of indices of systolic time intervals and the increased urinary excretion of catecholamines in patients with suspected acute myocardial infarction. Atterhög \& Ekelund (1) found shortened systolic time intervals in a group of asymptomatic young men with $T$-wave alterations in their electrocardiograms. In both studies an exaggerated sympathetic stimulation was considered to be the cause of the abbreviated systolic time intervals.

The thermometric data indicate that after the cold provocation test the workers with VWF exhibited more severe and more prolonged vasoconstriction in the digital vessels than those without VWF and the referents. This finding indicates that peripheral vascular hyperreactivity may be related to vibration exposure and to the severity of VWF. In conclusion, the present investigation suggests that vibration-exposed workers have an increased cardiac sympathetic tone. Hyperresponsiveness of the digital circulation to cold occurred to a larger extent in the workers with than in those without VWF. It is therefore likely that in the vibration group with VWF local circulatory disfunction, combined with an enhanced level of sympathetic nervous activity, lowers the threshold for the triggering of a finger blanching attack by vasoconstrictive factors such as cold, noise, and other environmental stress. The normality of platelet aggregation tests observed in this study tends to confirm that stages 1 and 2 of VWF are characterized by vascular disorders of functional origin.

\section{References}

1. Atterhög JH, Ekelund LG. Significance of primary T wave alterations in the electrocardiogram of asymptomatic young men: Part III Systolic time intervals and autonomic tone. Scand J Clin Lab Invest 40 (1980) 795-803.

2. Bovenzi M, Fiorito A, Giansante C, Calabrese $S$, Negro C. Platelet function and clotting parameters of vibrationexposed foundry workers. Scand J Work Environ Health 9 (1983) 347-352.

3. Gemne G. Pathophysiology and multifactorial etiology of acquired vasospastic disease (Raynaud syndrome) in vibration-exposed workers. Scand J Work Environ Health 8 (1982) 243-249.

4. Januszewicz W, Sznajderman M, Wocial B, Preibisz J. Urinary excretion of free norepinephrine and free epinephrine in patients with acute myocardial infarction in relation to its clinical course. Am Heart J 76 (1968) $345-352$.

5. Lewis RP, Boudoulas $\mathbf{H}$, Forester WF, Weissler AM. Shortening of electromechanical systole as a manifestation of excessive adrenergic stimulation in acute myocardial infarction. Circulation 46 (1972) 856-862.

6. Nerem RM. Vibration-induced arterial shear stress: The relationship to Raynaud's phenomenon of occupational origin. Arch Environ Health 26 (1973) 105-110.

7. Taylor W. Introduction. In: Taylor W, Pelmear PL, ed. Vibration white finger in industry. Academic Press, London 1975, pp XVII-XXII.

8. Weissler AM, Harris WS, Schoenfeld CD. Bedside techniques for evaluation of ventricular function in men. Am J Cardiol 23 (1969) 577-583. 